\title{
Study on the Mode of Improving the Ideological \& Political Education Quality of University Students in the Big Data Era
}

\author{
Teng Hui \\ Shandong University of Finance and Economics \\ Jinan, Shandong Province, China \\ sdieth@126.com
}

\begin{abstract}
As we all know, the arrival of big data era has brought great influence to social economy and people's daily life. Therefore, in order to improve the quality of ideological \&political education and promote the progress of ideological \&political work of university students, it is very important for the ideological \&political education in universities to be adapted to the development of big data era. This paper focuses on the topic of improving the quality of ideological \&political education. It briefly discusses the characteristics of ideological \&political education of university students in big data era and the challenges faced by the work of ideological \&political education, and it consequently concludes a mode to improve the quality of ideological \& political education.
\end{abstract}

Keywords-Big data; Ideological and Political Education; Mode of improving

\section{INTRODUCTION}

With the continuous progress of Internet technology, the big data technology has also been further promoted and applied in the education sector, and various network classroom teaching forms have been emerging which has brought convenience to the field of Internet education. Through the close combination of the ideological\&political education curriculum and the network classroom, it not only changes the learning environment of students, but also enhances the quality of ideological education. Therefore, under the situation of big data era, we should deeply study the technological advantages of big data, expand the scope of ideological education work through the scientific and reasonable use of it, and improve the quality of its educational work

\section{THE MAIN CHARACTERISTICS OF}

\section{IDEOLOGICAL\&POLITICAL EDUCATION OF UNIVERSITY} STUDENTS IN BIG DATA ERA

The extension of the scope of subject and object. The main body of ideological\&political Education in universities is all the students. Through big data technology to broaden the scope of data collection and do a detailed study of it, the teachers can master all aspects of the specific situation of the students. In the traditional education, due to the lack of time and energy, it is difficult for the teachers to do comprehensive and in-depth ideological education for every student. Nowadays, with the help of big data technology, the subject and object of ideological\&political education can communicate and interact through the network, and the teachers can carry out highly effective ideological\&political education for the vast majority of students without paying extra energy. This makes the relationship between the two more closely [1].

Diversification of carrier information. Under the background of big data era, the teachers should not only pay attention to the request accuracy of collecting data, but also grasp the overall trend of students' development, instead of paying too much attention to the information of a certain stage. For example, in the work of identifying poor university students, the teachers should not only make a further investigation into their family status, but also make an in-depth analysis of the students' consumption situation within six months, in order to obtain the true financial situation of the students. The teachers need not too much analysis of a particular item of the students' consumption.

The system becomes more complicated. Under the background of big data era, the collection of all kinds of information also becomes more convenient, which not only provides convenience for students to obtain information quickly, but also has a certain influence on their ideological cognition. The bad information in the Internet will have a negative impact on the formation of students' correct values and lead to errors in their social cognition. Therefore, it is necessary to block the bad information in the network to improve the students' ability to distinguish right from wrong, so that they can correctly face the various information in the network, thus reducing the influence of the bad factors on the students' psychological state. In addition, in the work of ideological\&political education, it is necessary to take into account the characteristics of the students to avoid the influence of the intensified education on the students' psychological independence so as to make a reasonable adjustment to their wrong ideological cognition. 


\section{CHALLENGES FACED BY IDEOLOGICAL\&POLITICAL EDUCATION IN BIG DATA ERA}

The Challenge of big data era to the university students' values. With the development of network technology and the emergence of various new media forms, a large amount of information is flooded in the Internet, including a considerable amount of negative information. The university students' thinking is active and they have strong curiosity about new things, but their ability to distinguish right and wrong needs to be strengthened. In addition, some students have deficiencies in self-restraint, which makes the students often lose themselves in the network. The above all produced negative impacts on the ideological education work in universities. For example, some students become indifferent to their study and life because they are intoxicated in the virtual world of the Internet, causing serious problems of Internet addiction. Due to the influence of unhealthy factors, it is difficult for some students to form correct values. In the context of big data era, everyone can express its opinions on the Internet, which makes a large number of positive and negative information mixed together, making it difficult for students to correctly handle the information. Inevitably, the students will be influenced intangibly, which will bring negative influence to ideological education. Therefore, the universities should use positive information to occupy the strategic high ground of the network and help the students to identify bad information and give the students correct ideological guidance [2].

The Challenge of big data era to the work environment of ideological\&political education in universities. Under the background of big data era, the quiet university campus is also affected by the information explosion. The traditional universities were relatively closed which means the students' contacting measures to the social outside world was less, they received less information, and their ideological situation were relatively simple, which made the ideological\&political education pressure relatively small. However, with the development of network technology and the emergence of various new media forms, the students are impacted by a large number of network information every day. At the same time, in our country, there are deficiencies in the supervision of various new media forms and network information, which makes a large number of bad information spread to the university campus through various new media channels, giving great influence on the students' world view, values view, and life view. Facing various unhealthy ideas, the university students often feel puzzled, which makes the educational environment of universities more and more complicated.

The Challenge of big data era to the subject of ideological\&political education in universities. In the traditional mode of ideological education, the school education method is relatively single, i.e. the teacher plays the absolute main role who is also the executor of the ideological education task, and the students are often in the subordinate position. Presently, due to the impact of the network information, the students are influenced by various ideas, which makes the ideological education work more complicated. In the face of this severe situation, the teachers should devote themselves to the improvement of their professional level, strengthen the ideological\&theoretical construction, actively try to open the classroom teaching, and change the content of teaching more diversified, in order to adapt to the development of big data era.

The Challenge of big data times to the traditional mode of ideological\& political education in universities. In the longterm practice of ideological education, the universities have formed a complete teaching mode and made remarkable achievements. The traditional education mode often use classroom instillation to focus on the effectiveness of classroom teaching. With the arrival of big data era, the students can obtain a lot of information through various ways, and gradually try to express their personal views on various issues and pursue the independence of their thoughts. This diversified choice of the students makes the traditional education mode gradually lose their due role, and can not meet the needs of ideological education work under big data era.

\section{THE MODE OF IMPROVING THE QUALITY OF} IDEOLOGICAL\&POLITICAL EDUCATION IN UNIVERSITIES IN BIG DATA ERA

Mastering and guiding the students' psychological and ideological changes in time. In order to improve the quality of ideological\&political education in the context of big data era, we must break away from the constraints of the traditional educational situation and do a large amount of information collection, collation and analysis of all aspects of the university students[3]. Then, according to the conclusion of the analysis, the existing educational resources are integrated and a multidimensional permeable education mode is established. Firstly, to use big data technology to construct a variety of ideological\&behavioral emergency mechanism. To collect, organize and analyze the students' consumption, attendance, browsing traces of the school's inner network and the data and information of various social media platforms, so that the students' ideological and behavioral status can be studied in advance. Thus, the students can be targeted to do ideological guidance work. Secondly, in addition to continuing to carry forward the advantages of traditional ideological\&political education, the schools should also do a good job in infiltrating ideological\&political education in various activities within the campus so as to closely link it with all aspects of school education, and the students then can be influenced by the education. Thirdly, we should pay attention to the innovation of educational form, try our best to use the way that students are willing to accept, strengthen the status of students' teaching subject, and maintain the good interaction between teachers and students. As long as they are actively involved in ideological\&political education, they can arouse the interest in learning, enable them to deeply understand and master the contents of ideological\&political education, and internalize it in the their comprehensive literacy. And they can be reflected in the daily behavior, so as to improve the quality of ideological\&political education.

Constructing the Internet ideological\&political education platform. Under the background of big data era, the universities should set up a network platform of ideological education, occupy the public opinion highland of the Internet with positive energy, guide the students to correctly face and deal with a large amount of data and information in the network, help them correctly identify the bad information, and enhance 
their discrimination level, so that the quality of network ideological education can be further improved. In order to be adapted to the development of network information, some universities have integrated the ideological\&political education network platform into the inner network, and set up relevant education courses in the mainstream media platform to build an open education platform. At the same time, some universities also specially set up the ideological\&political education website for the students, providing rich educational content for them, thus improving the quality of education. But during the construction of network education platform, the form and content of the platform set up by some universities are relatively single, and it is difficult to meet the specific needs of big data era, nor can it stimulate the students' learning enthusiasm. Therefore, the construction of the Internet education platform should keep up with the needs of big data era, enrich the form and content of teaching, and build a new type of platform system with the help of big data technology. So that the students can participate in the construction of educational platform spontaneously, can obtain the required knowledge from the platform, and improve their ideological\&political level.

Optimizing the working environment of ideological\&political education. The educational environment of the campus directly affects the ideological\&political education level of the students. The students' development during the university period is not only affected by the educational environment, but also maintains positive communication and interaction with the educational environment. Therefore, to construct the big data platform of ideological\&political education, the universities should first optimize the educational environment scientifically and rationally. Firstly, the university should strengthen the construction of campus civilization and occupy the main position in the new media platform. The university should give play to the positive role of the new media platform, actively carry out various interactive and open campus network cultural activities, and carry out ideological\&political education in new and unique forms. The construction of campus culture should be guided by socialist core values so as to establish a harmonious and civilized teaching environment. Secondly, it is necessary to strengthen the construction of students' psychological environment through various forms of education so that they can establish correct world view, values view and life view. Through the courses such as ideological\&political theory, psychological counseling, and the ways such as school education website, the student association and so on, the university carries out the socialism thought idea education, causes the university student to be able to firm the belief in the network information era, utilizes the big data era superiority to realize own social value.

Optimizing the subject of ideological\&political education. In the context of big data era, in order to improve the quality of ideological\&political education, we must enhance teachers' professional literacy in all directions, so as to realize the transformation of educational concepts, educational methods, ways of ideological communication, as well as teaching modes. The teachers should not only be able to understand and master the needs of ideological\&political work in universities, but also be able to use all kinds of new media on campus to spread correct ideological and moral concepts. In addition, the teachers should be able to get close to the students' behavior habits and language forms, to understand their various preferences and ideological conditions, so as to take the advantage position in carrying out the contents of ideological\&political education, following the trend of the development of students, going deep into the students' daily life and study, and improving the quality of education.

Optimizing the working methods of ideological\&political education. Firstly, the ideological\&political education work should make further innovation to the traditional education mode and method. Our country has decades of historical experience in ideological\&political education, and has also obtained remarkable achievements, which provides spiritual food for the progress of society and economy. Presently, although the traditional mode and method of education are limited by the era, we still need to improve and perfect the essence of the traditional education, innovate on the basis of the traditional education and give it a new life. For example, we deem the classroom teaching no longer be adapted to the development of society, but if the teachers use a language close to the life of the students to carry out classroom education, use various modern teaching aids, and use the current social hot issues at home and abroad to communicate and interact with the students, then the ideological education class can also get their favor. Secondly, the teachers should have the courage to try all kinds of new educational methods. With the development of society, the methods of education should be improved and innovated. Under the background of big data era, the students' thoughts are developing in a variety of ways. The teachers should change their traditional thinking and have the courage to try a variety of educational methods to carry out the work of ideological\&political education. And according to the specific conditions and needs of different students to make appropriate adjustments to meet the individual needs of the students. Nowadays, education is no longer confined to schools. The teachers should guide students into society so that the students can practice in society, practice their excellent ideological and moral quality, thus set up the core values of socialism. Finally, the teachers should be good at using various new media platforms, bring ideological\&political education into the construction of new media platforms, and closely combine the advantages of the traditional education mode with the new media education mode so as to perfect the system of ideological\&political education. The teachers should set up the website platform of the ideological education, and take the website platform as the public opinion position of the Internet ideological\&political education. The teachers should utilize the new media such as Weibo, WeChat, etc. to open up a new field of ideological\&political education and spread socialist core values, in order to enhance students' ideological and moral literacy. The teachers should utilize the mobile terminals such as mobile phones to carry out educational work in depth, so as to build a complete ideological\&political education mutual channels. 
Strengthening the construction of educational team. The university Counselors play a key role in the ideological education system. The working attitude of the counselors and the comprehensive professional quality of the counselors directly affect the quality of ideological\&political education. In order to give full play to their role in promoting ideological education, it is necessary to pay more attention to the counselors, improve their professional quality and moral accomplishment, so as to ensure the orderly development of the education work. In addition, according to the overall plan of ideological\&political education in university, the counselors should decompose it into specific task objectives to ensure the continuity of educational work. At the same time, the counselors should organize the students to participate in the formulation of detailed goals at each stage of study, and define each plan for classroom teaching activities. In this way, the communication and interaction between the teachers and the students can ensure the completion of the stage goal and improve the quality of ideological education.

\section{CONCLUSION}

To sum up, the universities should make further development and innovation on the traditional mode, teaching method and communication channel of ideological\& political education work by taking the technological advantage brought by the big data, and strive to improve the quality of education work. The universities shall correctly face the problems and shortcomings of ideological\&political education in big data era, and realize the innovation and development of educational work mode with the help of the technological advantage of big data, so as to give full play to the ideological\&political education work to promote the healthy development of the university students.

\section{REFERENCES}

[1] Liang Jiafeng, Qi Zhenhua, Adaptation and Innovation: Ideological\&political Education in Universities in big data era. [J] Ideological education research. 2013(06):63-67.

[2] Li Huaijie, Xia Hu, A probe into the Innovation of ideological\&political Education Mode in Universities in big data era $[\mathrm{J}]$. Research on ideological Education, 2015 (05): 48-51.

[3] Pang Suo, Weixing, The Application of big data in ideological\&political Education in universities [J]. Ideological theory Education, 2015 (06): 72-75. 